two areas, nor to their chronological position in relation to the amphibolites in the gneisses. The supracrustals might belong to the same unit as the amphibolites, or they might be younger.

The chronology for the basic dyke generations given in the previous reports has not been altered. It is of interest to mention that the Gardar dolerites (BDs) become fewer in the area north of Frederikshå.

\title{
References
}

Higgins, A. K. and Bondesen, E. (1966) Supracrustals of pre-Ketilidian age (the Tartoq Group) and their relationships with Ketilidian supracrustals in the Ivigtut region, South-West Greenland. Rapp. Grønlands geol. Unders., Nr. 8.

Jensen, S. B. (1966) Field work in the Frederikshåb area. Rapp. Gr $\phi$ nlands geol. Unders., Nr. 11, 32-35.

Jensen, S. B. (1968) Field work in the Frederikshåb area. Rapp. Grønlands geol. Unders., Nr. 15, 40-44.

Windley, B. F., Henriksen, N., Higgins, A. K., Bondesen, E. and Jensen, S. B. (1966) Some border relations between supracrustal and infracrustal rocks in South-West Greenland. Rapp. Grønlands geol. Unders., Nr. 9.

\section{A KIMBERLITE DYKE IN THE NIGERDLIKASIK AREA, FREDERIKSHÅB DISTRICT}

\author{
J.R. Andrews
}

During recent geological mapping of the Nigerdlikasik area, $45 \mathrm{~km}$ due east of Frederikshåb, an intrusive diatreme was discovered. This takes the form of a $50 \mathrm{~cm}$ wide vertical dyke, tracable for at least 500 metres. It can be demonstrated that the petrographic features of this and several other bodies occurring in the vicinity, e.g. in the Tigssaluk granite (Emeleus, 
1958) and on Midternæs, (A.K. Higgins, personal communication), conform to the definition of a kimberlite as outlined by Dawson (1967).

The Nigerdlikasik dyke is composed of a coarse-grained matrix bearing local and exotic inclusions. The matrix consists of xenocrysts of fresh olivine up to $5 \mathrm{~mm}$ in diameter and lying in a carbonated serpentine/ chlorite groundmass. Two generations of olivine have been distinguished: deformed large ragged rounded crystals and smaller euhedral to subhedral crystals. Fresh phlogophite mica is always present. Red margins to the phlogophite may be xanthophyllite, resulting from reaction with a Ca-rich fluid during intrusion. Magnetite/ilmenite is common and may surround small round crystals of perovskite. Apatite is a well formed accessory. A bulk chemical analysis of the dyke matrix is in close agreement with other kimberlite analyses to be found in the literature.

The fresh rock is dull dark grey. In the field it is brown with a rough surface caused by the weathering of the carbonate matrix leaving protruding olivine xenocrysts. In several places concentrations of elongate nodular inclusions up to $15 \mathrm{~cm}$ long have been found. These inclusions fall into three main categories:

(i) Ultrabasic nodules consisting of four mineral phases; olivine, enstatite, chrome diopside plus either pyrope garnet or chrome spinel. They have a deep-seated origin, probably in the mantle. Using electron probe microanalysis it has been shown that the mineral compositions of these nodules agree closely with those observed in South African kimberlites (Nixon et al., 1963).

(ii) Nodules with a deep crustal mineralogy among which granulites and eclogites are represented.

(iii) A series of more angular inclusions of local country rock.

The true age of the Nigerdlikasik kimberlite is uncertain. The dyke cuts the pre-Ketilidian gneissic basement complex and early posttectonic basic dykes. It may be co-genetic with the carbonatite lamprophyres occurring in a NW-SE-trending swarm at the coast near Frederikshåb (Walton, 1966) which gave a Mesozoic age, $162 \pm 5 \mathrm{~m} . \mathrm{y}$. (Larsen and M $\phi 1 \mathrm{ler}$, 1968). It is interesting to note that a date of $151 \pm 8 \mathrm{~m}$. y. has recently been obtained from a kimberlite in Ontario, Canada (Lee and Lawrence, 1968). 


\section{References}

Dawson, J. B. (1967) A review of the geology of kimberlite. In Wyllie, P. J. (edit.) Ultramafic and related rocks, 241-251. London: Wiley.

Emeleus, C. H. (1958) The granites of the Tigssalug area, S. W. Greenland. Unpubl. rep., Grфnlands geol. Unders.

Larsen, O. and M $\varnothing l l e r$, J. (1968) K/Ar age determinations from western Greenland I. Reconnaissance programme. Rapp. Grønlands geol. Unders., Nr. 11, 82-86.

Lee, H. A. and Lawrence, D. E. (1968) A new occurrence of kimberlite in Gauthier Township, Ontario. Geol. Surv. Can. Paper 68-22.

Nixon, P. H., Knorring O. von and Rooke, J.M. (1963) Kimberlites and associated inclusions of Basutoland; a mineralogical and geochechemical study. Amer. Min。, Vol. 48, 1090-1132.

Walton, B.J. (1966) Carbonatite-lamprophyre dykes of Mesozoic age. Rapp. Grфnlands geol. Unders., Nr. 11, 37-38.

\section{FIELD WORK IN THE ILÍMLAUSSAQ INTRUSION}

\section{H. S $\phi r e n s e n$}

In the summer of 1968 the detailed mapping at scale $1: 2000$ of the Kvanefjeld region in the northernmost part of the intrusion was practically completed. During this study four types of uranium deposits have been established:

1. A zone of contact alteration around late veins and sheets of a medium - to coarse-grained lujavrite which is confined to a horizon between the roof of gabbro, lava, etc. and an underlying zone of syenites veined by fine-grained lujavrite (cf. S $\phi$ rensen, Hansen and Bondesen, 1969). This deposit was examined in $36 \mathrm{drill}$ holes in 1958 and found to contain 4000 tons 